\author{
УДК 87.3:159.9(2) \\ ББК $83.3: 88.1(2)$ \\ Thomas Nemeth \\ United States of America, New York, e-mail: t_nemeth@yahoo.com
}

\title{
Chelpanov: The Psychologist as a Realist Neo-Kantian
}

Annotation. This essay explores the writings of Georgij Chelpanov, who recognized the value of both psychology and philosophy, much to the displeasure of all. Chelpanov only very guardedly expressed his own philosophical views, which stand, I conclude, in stark contrast with the neo-Kantianisms of both the Marburg and the Baden Schools. We see that in his earliest writings on spatial perception, he not so much differs with Kant as saw the matter from a different perspective. Nonetheless, he shares Kant's affirmation that the universality and necessity associated with our representation of space affirms its apriority as a condition of cognition, particularly with respect to mathematics. Chelpanov departs from Kant in rejecting the exclusive subjectivity of space and time, arguing that there is something in noumenal reality that corresponds to our specific representations of an object's temporal and spatial position. Otherwise, there is no way to account for their specificity, for why a perceived object is here and not there. Chelpanov argues this from a psychological viewpoint, but he acknowledges that Kant argues from a logical viewpoint. Turning to the issue of free will, he, in short, argues for a soft determinism that is quite consistent with Kantianism, even though Chelpanov's argument is bereft of the metaphysics and the architectonic of Kant's system. In conclusion, although scholars dispute his allegiance to neoKantianism, his philosophical writings demonstrate his subdued advocacy of a neo-Kantianism, albeit one more akin to the transcendental realism of Riehl and Paulsen.

Key words: Georgij Chelpanov as realist, Stumpf's departure from Kant, perception of space, moral argument for free will, Riehl on space and time, causality, neo-geometry as a philosophical problem, Chelpanov's criticism of neo-Kantian idealism

\section{Томас Немет}

Соединенные Штаты Америки, Нью-Йорк, e-mail: t_nemeth@yahoo.com

\section{Челпанов: психолог как реалист-неокантианец}

Аннтотация. Исследуются труды Георгия Челпанова, который признавал ценность как психологии, так и философии. Философские взгляды Г. Челпанова резко контрастируют с неокантианством как марбургской, так и баденской школ. Анализ самых ранних работ Г. Челпанова о пространственном восприятии показал, что он не столько расходится с Кантом, сколько разделяет его утверждение о том, что универсальность и необходимость, связанные с нашим представлением о пространстве, подтверждают его приоритетность как условие познания, особенно в отношении математики. Взгляды Челпанова рассматриваются как идущие от Канта в отрицании исключительной субъективности пространства и времени. Утверждается, что, согласно Канту, в ноуменальной реальности есть что-то, что соответствует нашим специфическим представлениям о временном и пространственном положении объекта. Г. Челпанов аргументирует эту позицию с психологической точки зрения, но признает, что Кант рассуждает с точки зрения логики. Обращаясь к вопросу о свободе воли, он отстаивает мягкий детерминизм, вполне совместимый

(C) Томас Немет, 2021

Соловьевские исследования, 2021, вып. 2, с. 84-113 
с кантианством, хотя аргумент Челпанова лишен метафизики и архитектоники системы Канта. В заключение утверждается, что, хотя ученые оспаривают приверженность Челпанова неокантианству, его философские труды демонстрируют сдержанную защиту неокантианства, хотя и более близкого к трансцендентальному реализму Риля и Полсена.

Ключевые слова: Г. Челпанов как реалист, К. Штумпф и Кант, учение Канта о пространстве и времени, моральный аргумент и свобода воли, А. Риль о причинности, пространстве и времени, неевклидовы геометрии, Челпанов как критик неокантианского идеализма

DOI: $10.17588 / 2076-9210.2021 .2 .084-113$

In the last years of the nineteenth century, a central and heated debate raged whether psychology was a natural science or a branch of philosophy. Some pondered whether the introduction of experimentation in studies of the mind would assist our understanding of philosophical issues, perhaps even solve them. Russian academics faced these concerns and prospects no less than their colleagues in western Europe and America. In Imperial Russia, the controversy took on a political and theological coloring, making an impartial adjudication of the matter difficult, if not impossible. For some asked the question: if the human mind could be studied by natural means, would that not strike a blow against the Biblical teaching that the human being was created in the image and likeness of God? Does not experimental psychology mean that we can know the Divine by natural, empirical means? Some investigators, torn between the world of philosophy and that of experimental psychology could not unambiguously choose and preferred to leave their allegiance ambiguous. Chelpanov was one such scientist.

\section{The Preparatory Years in Kiev}

Georgij I. Chelpanov (1862-1936) was born in Mariupol. After completing his secondary education in 1883 at a local school and allegedly already attracted to studying psychology, he entered the university in Odessa, where Nikolaj Ja. Grot (18521899) had recently assumed a professorship. ${ }^{1}$ Chelpanov graduated in 1887 and was recommended to pursue further studies at Moscow University. In a few years, he was teaching as а приват-доцент there, but in 1892 he accepted a position at Kiev University. In the mid-1890s, he went to Germany, where he was able to attend lectures by Stumpf and Wundt. He defended a магистер thesis in 1897, followed by a doctoral dissertation in 1904. Most of his writings over many years reflected his deep pedagogical concerns rather than an attempt to present and to argue for his own philosophical position. This is particularly the case with his first publications. In fact, it

\footnotetext{
${ }^{1}$ Chelpanov wrote years later that upon finishing his secondary education he had to decide which university to attend. With a firm desire to pursue psychology, Grot's presence in Odessa was decisive: "All of my sympathies were on the side of N. Ja. Grot”. Челпанов Г.И. Памяти проф. Н.Я. Грот // Николая Яковлевича Грот в очерках, воспоминаниях и письмах. СПб.: Тип. Кушнерев, 1911. С. 188 [1].
} 
is surprising how little he clearly revealed of his own stance - assuming he had one in so many of his own publications. ${ }^{2}$ This reticence, whether deliberate or not, in the secondary literature surely lies behind the failure to reach a consensus as to Chelpanov's relation to Kant and, more specifically, to neo-Kantianism, however that may be understood.

We cannot possibly hope to survey here all of Chelpanov's extensive list of works, many of which are concerned with experimental psychology and as such have little bearing on the present topic. He also authored a number of purely expository pieces, explaining the works of others and the latest advancements in scholarship abroad. In this essay, we shall proceed chronologically as much as possible. In this regard, in what may well have been the first statement of his relationship to Kantian philosophy, Chelpanov took up in 1893 a comparatively brief study of inner timeconsciousness. With respect to the age-old problem concerning the nature of time, Chelpanov thought it most useful to study how we perceive it, i.e., its psychological nature, how it appears to each of us, rather than objective time. It is strictly from that point of view that he intended to examine the question. Thus, Chelpanov's exposition bears a greater similarity to Husserl's work on the topic - minus any "transcendental reduction" - than it does to Kant's treatment in the "Transcendental Aesthetic". Chelpanov made a sharp distinction between what he termed "mathematical time" and "psychological time". The former is abstract. Just as we distinguish the mathematical representation of a line from the representation of a line drawn on paper, so too can we distinguish between the time measured by clocks, "mathematical time" and our inner awareness of the passage of time, "psychological time". Contra Kant in the "Aesthetic", we cannot think of either space or time as completely empty of representations. ${ }^{3}$ Chelpanov wrote, "we can as little intuit time devoid of content as we can intuit space without filling it with content" [4, c. 48]. Although we may conclude from this that Chelpanov's opposition to Kant in this instance is a simple proof that the former was not a Kantian (or neo-Kantian), it did not appear to Chelpanov that he was contradicting Kant. For in Chelpanov's estimation, Kant had in mind not psychological time, i.e., inner time-consciousness, but mathematical time, which is infinite, continuous, and uniform. ${ }^{4}$ Time is subjective and an a priori property of the

\footnotetext{
${ }^{2}$ In a revealing statement of his fundamental outlook presented in a public lecture in 1902, Chelpanov said, "It would seem most natural in this case to present my own idealistic system. However, since this presentation of public lectures must be brief, it would have to bear a dogmatic character. ... I will survey the philosophical constructions that were proposed in the second half of the nineteenth century in order to show that philosophical thought unavoidably had to pass from positivism to metaphysical idealism”. Челпанов Г.И. О современных философских направлениях / под ред. Густав Шпет. К.: Тип. Петр Барский, 1902. С. 4 [2].

3 "In regard to appearances in general one cannot remove time, though one can very well take the appearances away from time". Kant I. Critique of Pure Reason / trans. Paul Guyer and Allen W. Wood. Cambridge: Cambridge University Press. 1997. C. 178-179 (A31/B46) [3].

${ }^{4}$ This, of course, flies in the face of several arguments in Kant's metaphysical expositions of space and of time, which Chelpanov, however odd it may appear, did not acknowledge.
} 
mind, but Kant's idea of time is not what Chelpanov thought he was investigating. Based, then, on what he wrote, Chelpanov in 1893 was committed to neither an acceptance nor a rejection of Kantianism.

Chelpanov's concern with our psychological conception of space, which obviously consumed a significant measure of his attention, dated back at least to 1884, when he gave a presentation on «Учение о пространстве у Канта и в современной психофизиологии» while still a student. However, Chelpanov's major work on the topic was undoubtedly his магистер thesis, the defense of which took place in late October 1896, the opponents at the defense at Moscow University being Grot and Lopatin. ${ }^{5}$ In the «Предисловие» to this work, Chelpanov wrote that his fundamental concern was philosophical: the structure and origin of our representation of space. The choice of topic evokes Stumpf's own earlier work from 1873 on the psychological origin of our representation of space Über den psychologischen Ursprung der Raumvorstellung, with which Chelpanov clearly was familiar. The similarity was unlikely coincidental. In any case, Chelpanov added that he must ultimately address additional questions: Is the representation of space original or derivative? Is it simple or compound? He hoped to address the problem of the origin and the structure of space by means of an analysis of psychological facts and laws. However, the fundamental task remained a philosophical problem. The turn to psychology serves merely as a preliminary, though necessary, investigation in order to prepare for a confrontation with the philosophical problem.

It is not always easy to follow Chelpanov's presentation with its many distinctions that, in effect, obfuscate rather than help clarify whether he belonged at an early date to the neo-Kantian camp. It is even more difficult, as a consequence, simply to determine Chelpanov's viewpoint. Kant's theory of space, he acknowledged, is not in the rigorous sense a psychological theory, but an epistemological one. Since Chelpanov's investigation in this work was intentionally of a psychological nature, we should not be surprised if we were unable to find any textual evidence to support one position or another in the matter. Fortunately, however, this is not entirely the case. Chelpanov contrasted genetic or empiricist theories of spatial representation with nativist theories. Genetic theories hold that the operation of separate mental processes form the mental representation of space from non-spatial elements in sensation, whereas nativist theories are defined as those that view spatial extension as sensed just as are other properties of things, such as color. ${ }^{6}$ Chelpanov contended that

\footnotetext{
${ }^{5}$ Many sources place the date of the defense in 1897, without providing a source. One gives it as occurring on 25 October 1896, the year of the publication of the thesis itself. См. Рубцов В.В., Серова О.Е., Гусева Е.П. К 150-летию со дня рождения Георгия Ивановича Челпанова // Культурноисторическая психология. 2012. № 1. С. 97 [5].

${ }^{6}$ Although he ascribed this position to others, Chelpanov omitted that Kant did not view the representation of space as comparable to our representation of color. Indeed, several years earlier Chelpanov wrote, "According to Kant, the intuition of space is a subjective form of intuition similar to qualities of sensation, to red, to sweetness, to cold". Челпанов Е.И. Гельмгольц как философ и психолог // Вопросы философии и психологии. 1891. Кн. 10. С. 43 [6]. Kant, in contrast, wrote, taste and colors
} 
Kant's position belongs among the geneticists, since "he could not recognize the immediacy of our perception of the spatial quality as did the nativists" [7, c. 9n.]. ${ }^{7}$

Chelpanov, indeed, saw Stumpf as criticizing Kant. Space, for Stumpf, is inseparable from sensation. Criticizing Kant's abstraction argument, a space without qualities, Stumpf wrote, "One cannot represent space without some quality, e.g., not without color through our sense of sight, without feelings of contact through our sense of touch. ... Anyone who actually attempts to carry out Kant's experiment by eliminating all qualities, particularly all colors, even black and gray, will be left not with space, but with nothingness" [11, c. 19-20]. We see here a coincidence with Chelpanov's earlier statement to the same effect. In fact, he stated that although he had objections to some parts of Stumpf's statement he could not help but admit that Stumpf's resolution of the problem had indubitable merits. More than others, Stumpf consistently developed the nativist principle. ${ }^{8}$ Since Stumpf explicitly distinguished his position from Kant's, and Chelpanov, albeit with qualifications, endorsed Stumpf's, it is becoming unclear on what basis we could characterize Chelpanov as a neo-Kantian at least in the 1890s. Can someone who holds different views than that of Kant as expressed in the Transcendental Aesthetic but who is silent on the Kantian tenets be labelled meaningfully as a Kant or a neoKantian? Or is such a judgment, however tentative, premature?

Let us proceed further in Chelpanov's first publications. Following an earlier path carefully treaded by Stumpf, Chelpanov characterized the representation of space, considered quantitatively, as consisting of parts, i.e., that it can be conceptually broken down or reduced, although we do not consciously see it as such. More importantly, he again affirmed that spatial extension is as much an aspect of a sensation as is its intensity. As an object, extension has no meaning apart from what is sensed. ${ }^{9}$ He wrote,

\footnotetext{
"are not a priori representations, but are grounded on sensation". Kant I. Critique of Pure Reason / trans. Paul Guyer and Allen W. Wood. Cambridge: Cambridge University Press. 1997. C. 161 (A29/B44) [3].

${ }^{7} \mathrm{He}$ returned again and again to this topic in subsequent years. For example, he wrote in 1903, "Many think that Kant was a nativist in his theory of space, but this is incorrect. Kant was not interested in whether the representation of space is acquired gradually or whether it forms an innate property". Челпанов Г.И. 1903. Психология и теория познания // Вопросы философии и психологии. 1903. Кн. 67. С. 174 [8]. This assertion is not quite correct. In his 1790 response to Eberhard, Kant wrote that the formal ground of the possibility of intuiting space is innate, but not the spatial representation itself. Kant I. Theoretical Philosophy after 1781. Cambridge: Cambridge University Press. 2002. C. 312 (Ak 8: 222) [9]. See also his 1770 Dissertation, Kant I. Theoretical Philosophy, 1755-1770 / trans. and ed. David Walford and Ralf Meerbote. Cambridge: Cambridge University Press. 1992. C. 400 (§15, Ak 2: 406) [10].

${ }^{8} \mathrm{See}$ Челпанов Г.И. Проблема восприятия пространства в связи с учением об априорности и врожденности. Часть I: Представление пространства с точки зрения психологии. К.: Типография Кушнерев. 1896. С. 121 [7].

${ }^{9}$ Stumpf had earlier made the same point in asking, "Cannot both contents of sensation - space and quality - be given in an immediate sensation in the same way?". Stumpf C. Über den psychologischen Ursprung der Raumvorstellung. Leipzig: Hirzel. 1873. C. 15 [11].
} 
I hold the position that extension is just as much a moment of sensation as is intensity. In general, by "moment" I mean something that in a given appearance has no independent meaning. For example, the quality and the intensity of a sensation are moments, because neither of them can exist independently. They can be conceived separately from other moments only in abstracto [7, c. 150-151].

It is not clear in this, though, that Chelpanov departed significantly from Kant. The latter in the second argument of his Metaphysical Exposition asserted the psychological impossibility of imaging objects apart from space. ${ }^{10}$ Chelpanov, however, was concerned, above all, with the perceiving or sensing of objects. He agreed with Kant that we can separate spatial extension in thought, i.e., abstractly, from the particular contents of sensation. Kant's concern, however, was different from Chelpanov's, and as a result we can view Chelpanov not as differing with Kant, but as viewing the matter from a different perspective. Chelpanov did not disagree, though, with Kant's affirmation that the universality and necessity associated with our representation of space affirms its apriority as a condition of cognition.

Kant's third argument in the second, or B-edition, of the first Critique holds that "one can only represent a single space, and if one speaks of many spaces, one understands by that only parts of one and the same unique space" [3, c. 158 (A25/B39)]. Chelpanov alluded to the same point. He asked what do people see when they open their eyes for the first time. The original object of perception is a general spatial field populated with separate elements that subdivide, as it were, the spatial field and that the objects "determine the interrelation of the separate parts of space, their relative positions, etc." [7, c. 168]. He added that it does not follow from this - although it may seem to do so at first - that our awareness of space, i.e., our representation of it, is constructed from these separate elements. Chelpanov ever so guardedly opined, writing that "in all probability" the formation of our representation of space is not from parts to whole, but rather just the reverse. He, thereby, added his qualified support for Kant's stand that space is not discursive, but a pure intuition. Whereas Kant remained content without inquiring into the physiological basis for our intuitive representation of space, others later were not. None, though, could successfully explain space. Chelpanov held that neither Johann Herbart, Kant's successor in Königsberg, nor Wundt could demonstrate how the representation of extension could arise from non-spatial elements. The representation of extension cannot be produced from what does not possess extension any more than can the representation of color be assembled from color-less elements. In Chelpanov's eyes, in short, space is underived. "It is impossible to prove that space is composed of non-spatial elements" [7, c. 378].

\footnotetext{
${ }^{10}$ See Kant I. Critique of Pure Reason / trans. Paul Guyer and Allen W. Wood. Cambridge: Cambridge University Press. 1997. C. 158 (A24/B38-39) [3]. It is admittedly not uncontested that the second argument asserts a psychological impossibility.
} 
However, even should we concede the non-reductionist position, one may argue that the argument establishes only that our representation of space is an a priori condition of our representation of empirical objects. The argument alone, as Paul Guyer has more recently pointed out, does not entail the transcendental ideality of space itself - what space is - without an additional argument that apriority entails such ideality. Unlike Kant, Chelpanov was usually careful not to confuse our (psychological) representation of space with ("objective") space itself, though as we just saw and will continue to see he did not always do so. ${ }^{11}$

Chelpanov's primary interest in the emerging field of experimental psychology during the 1890s did not totally exclude him from venturing into the philosophical arena. One such incursion was his contribution to the popular monthly journal Mir Bozhij [God's World] on the perennial issue of free will/determinism. Although he spent far more time discussing Mill than Kant, Chelpanov largely concurred with Kant's position, albeit without entering into the complexities of or even assenting to Kantian idealism. Chelpanov conceded that Kant's stand was not without contradictions and imprecisions. Nevertheless, its kernel contains an indubitable truth that can be understood with effort and recognized as correct, although with even greater effort. Here lies the "kernel" for regarding Chelpanov to be, at least in part, a neoKantian. Thus, let us look a little closer at his view.

Chelpanov in his popular exposition "О свободе воли" discussed what for him are the three types of proof in support of free will: (1) the psychological proof, the thesis of which is that we "feel" the will acts without causes; (2) the metaphysical proof, the thesis of which is that the will can act originally on the body and, therefore, can violate universal causality; and (3) the moral proof, the thesis of which is that our sense of responsibility for our actions presupposes a free will. We indubitably have such a sense of responsibility, therefore we have a free will. ${ }^{12}$ Chelpanov had no need to invoke the physicist's notion of universal causality. As a psychologist, he could see that every willful action has a definite motive, and as an experimentalist he would be unable to engage in objective investigations of behavior if he

\footnotetext{
${ }^{11}$ Chelpanov's book received a rather stinging review in the hands of N. Ja. Grot, who wrote that by counting Kant as a geneticist in the theory of space Chelpanov obviously revealed his untenable starting point and the inadequacy of his method as demonstrated by his subjugation of epistemology to psychology. Kant's standpoint was, contrary to Chelpanov's reading, purely epistemological, not psychological. Грот Н.Я. 1896. [Рецензия] Челпанов. Проблема восприятия пространства в связи с учением об априорности и рожденности // Вопросы философии и психологии. 1896. Кн. 35. С. 653 [12]. However, Chelpanov refused to concede. As we saw, Chelpanov acknowledged that Kant's standpoint was essentially epistemological, and in a reply to Grot, he pointed this out. See Челпанов Г.И. 1897. К вопросу о восприятии пространства // Вопросы философии и психологии. 1897. Кн. 37. С. 278 [13]. Chelpanov also pointed out in this reply that he did not explicitly subordinate epistemology to psychology. Rather, "the philosophical problem of space must be examined jointly from both the psychological and the epistemological viewpoints. ... It seems to me that the elaboration of empirical psychology is, to a certain degree, just as independent of epistemology as it is of physics and chemistry". Там же. С. 277.

${ }^{12} \mathrm{See}$ Челпанов Г.И. 1897. О свободе воли // Мир Божий. 1897. № 11. С. 18 [14].
} 
denied the link between the will and human action. That we "can more or less precisely predict human actions" would be impossible if causality did not operate in the psychic sphere.$^{13}$ If contingency reigned there, if certain causes did not regularly and consistently evoke the same actions, psychology would be a useless enterprise. Chelpanov recognized that this attitude did not amount to a definitive refutation of the psychological and the metaphysical proofs. However, he stressed that he merely wished to defend free will by way of the third proof, i.e., the moral proof, and thus independently of first making a physicist's determination of whether the will is uniformly caused or not.

That we have a sense of responsibility for our actions testifies to our free will for all practical purposes. Our awareness that we are the true cause of our actions follows from that sense. Chelpanov held, though, that this is an ethical, not a metaphysical, proof for the existence within us of a free will. At the same time, responsibility also entails that our actions are subordinate to the law of causality. If our actions were uncaused, punishment for incorrect behavior would be meaningless. On the other hand, that we are punished for incorrect behavior shows that society recognizes that individuals can and should control their actions. Chelpanov, in short, argued for a soft determinism quite consistent with Kant's teaching even though it is bereft of much of Kant's metaphysics and the architectonic of Kant's system.

Before turning to his philosophical writings intended for a professional audience, let us turn to one essay published at the beginning of the century that Chelpanov had intended to introduce Kant to a broad, educated public. Much that he said in this four-part piece is a simplistic but uncontroversial elaboration of the essential points Kant enunciated in his three Critiques. Nevertheless, Chelpanov made the rather odd claim - from a Kantian standpoint, that is - that for Kant there is $o b$ jectively nothing that corresponds to the concepts of space and time, that "space and time, as we conceive them, have only a subjective existence" $[15$, c. 18$] .{ }^{14}$ Such a statement, of course, makes us question how he understood Kant's transcendental idealism. In Chelpanov's eyes, Kant argued for space and time as having not an absolute, but merely a subjective, existence, that "we perceive things not as they are in reality" [15, c. 22]. Chelpanov did acknowledge that mathematics is an objective science in that its objects are the subjective forms of space and time. He concluded from this that Kant's theory is, consequently, a subjective idealism, a phenomenalism. Although today few would so characterize Kant's position, we must recognize that Chelpanov here was writing for a lay audience and that apart from whether he "correctly" depicted Kant's positions we cannot conclude whether he personally agreed or disagreed with the positions he attributed to Kant. For this reason, we must pro-

\footnotetext{
${ }^{13}$ See Челпанов Г.И. 1897. О свободе воли // Мир Божий. 1897. № 11. С. 46.

${ }^{14}$ However we may chafe at some of Chelpanov's wording, we should not forget that Kant at times expressed himself in words that conjure a similar impression. For example, he wrote that space and time are representations, "which dwell in us as forms of our sensible intuition before any real object has even determined our inner sense through sensation..." [3, c. 428 (A373)].
} 
ceed cautiously - though that is difficult - concerning what we ascribe either to Chelpanov's understanding of Kant or to his own personal standpoint.

Chelpanov was largely silent on the complexities of the synthesizing process in Kant's first Critique. He characterized the twelve Kantian categories, i.e., those listed in $\S 10$ (A80/B108), as forms added by consciousness in a manner similar to the way in which space and time are added to our raw sensations. However simplistic this may sound, Chelpanov at least expressed his own opinion that this additive process is not psychological, but logical. He expressly noted that in writing of the apriority of space and time Kant's interest was in the objectivity of mathematics. ${ }^{15}$ [15, c. 183].

Chelpanov also in this popular survey of Kant's thought discussed his ethics and aesthetics. As we saw above, Chelpanov saw Kant proceeding from a recognition of the real necessity of the moral law to its presupposition in a free will. "Clearly in order to submit to the moral law freedom is necessary. Freedom is a necessary condition for the existence of the moral law itself" [15, c. 66]. The ultimate message, though, was religious. The important point contemporary philosophy was to learn from Kant is that faith occupies an equal position in our worldview with knowledge. The world of science and mathematics is not reality in itself, but only an appearance, whereas the world of religion is the supersensual reality itself ${ }^{16}$

\section{The a priori Understood Psychologically}

At the start of the $20^{\text {th }}$ century, Chelpanov published several philosophical articles aimed at a technically-sophisticated audience and that alluded to what would become the central topic of his later thesis. The goal of the first of these essays was to determine whether there are a priori cognitions or a priori elements of cognition. He alleged that the simplest approach to the issue is by way of considering the concept of number. Chelpanov sought to show that that concept is a priori, and not obtained from sense experience, this contrary to Mill's version of empiricism [16, c. 537]. We must admit that Chelpanov's exposition is admirably lucid, even though his arguments hardly break new ground. We need not even summarize them here; they are only too familiar. Few in either his own day sought - or in our day seek - to uphold Mill's philosophy of arithmetic. Of somewhat greater interest, in any case, is that Chelpanov, having dispensed with Mill's account, persisted, stating that "we must seek the origin of the idea of number not in changes in the physical facts, but in some feature of consciousness itself" [16, c. 548].

For Chelpanov, the concept of number can be traced to an abstraction from pauses in conscious processes. We obtain the concept through an implicit reflection on our inner observation of those processes, and not as the empiricists claim through

\footnotetext{
15 Челпанов Г.И. Философия Канта. Статья 1-я (Теоретическая философия) // Мир Божий. 1901. № 4. С. 183 [15].

${ }^{16}$ Там же. С. 70-71.
} 
observing objects and their qualities. In apprehending two temporally separated events or items, we apprehend not only those events but also the pauses between the two apprehensions. Chelpanov held, in short, that we attend to these pauses: "I notice that in order to perceive two peals of a bell, I have to do something different than when I perceive one peal. ... This difference in the number of pauses of consciousness becomes the source of the idea of number" [16, c. 549]. ${ }^{17}$ I can perceive these pauses in consciousness regardless of whether the intentional object is empirical or imaginary, really present or only in my memory. Thus our concept of number has its origin in an act of reflection. Arithmetical laws have their seat not in the empirical world, but express only laws of consciousness. Not being, strictly speaking, of empirical origin, arithmetic and the concept of number are a priori and cannot be either proven or refuted by external sense experience. Since the concept of number is not derived from something material, it is formal. We also see that conscious processes play an active role in the formation of arithmetic and that these pauses in conscious acts are inherently temporal cessations of mental acts. In this way, an inner awareness of time is involved in the formation of arithmetical concepts and laws. Lastly, if we consider concepts that are logical conditions of experience but that are not derived from experience to be a priori, then the concept of number is, by definition, an a priori concept. Its content is not obtained from experience, but at the same time we ascribe numerical properties to experiential objects. ${ }^{18}$

In summary, Chelpanov's view of the concept of number shares certain distinct similarities to Kant's. Both held it to be a priori, formal, based in inner timeconsciousness, and a condition of experience. For both, counting is a temporal process. ${ }^{19}$ However, Kant - thankfully - failed to emphasize the apparent psychological process involved in the emergence of number that is so prominent in Chelpanov; there is also no mention of a synthesizing process. On this basis, we can consider Chelpanov's philosophy of arithmetic to be in the spirit of Kant, i.e., neo-Kantian, were it not for his obvious omission of invoking Kant in any manner therein.

In the second of his two-part study, «Об априорных элементах познания», subtitled «Понятие времени, причинности, пространства», Chelpanov expressed

\footnotetext{
${ }^{17}$ One could possibly reply to Chelpanov noting that in his depiction of the origin of the concept of number the concept is already presupposed. How could someone "count" the pauses unless that person already has the concept of a number? Additionally, we must leave aside here a Kantian technical objection to Chelpanov's depiction of the origin of number. Namely, by counting the pauses in reflective consciousness Chelpanov would have us come to an image of a specific number, but the thought of a number in general "is more the representation of a method for representing a multitude ... than the image itself" [3, c. 273 (A140/B179)].

18 The reader, hopefully, will realize this author simply wishes to determine Chelpanov's position vis-àvis Kant, not to defend Chelpanov's theory of the origin of numbers by means of purely subjective mental operations.

${ }^{19}$ Kant, in the Prolegomena, wrote, "Even arithmetic forms its concepts of numbers through successive addition of units of time, but above all pure mechanics can form its concepts of motion only by means of the representation of time" [9, c. 79 (Ak 4:283)].
} 
his own position far more audaciously than previously. He claimed that the concept of time, along with that of number, is a priori. In other words, there is nothing objective in the external world that corresponds to time in the way that we can say of a particular color that there is something, such as a chemical, in an externally existing object that absorbs all wavelengths of light except that which corresponds to that color. "There is no doubt that time really exists in our consciousness, but it is also indubitable that it does not exist in nature, objectively. ... In nature, there objectively are events or phenomena, the perception of which is merely the occasion for the emergence of the concept of time" [17, c. 699]. Thus, time is a product of a distinctive activity of consciousness itself. Yet a mere alteration of events or phenomena would be insufficient for us to have a concept of time. Chelpanov held that the changes must recur in a regular order, for we must be able to establish a definite connection between the representations of the events. "Therefore, the most characteristic feature of temporal relations is the representation of succession, i.e., that we conceive events as following one after another. But the condition just given must be fulfilled in order for there to be such a representation" [17, c. 703]. Our representation of temporal succession, while not empirically given, would not arise in consciousness were it not for what Hume called "impressions". Objectively, there are only sounds, color, etc., but no succession. We ourselves create it by connecting individual impressions. The job of psychology is to furnish more information about this connecting process, which, in any case, is subjective, i.e., an activity of consciousness. The concept of time is a product of reflection. ${ }^{20}$ The singularity of time, of which Kant wrote, led him to view time as an intuition. ${ }^{21}$ In this, Chelpanov believed Kant had inferred incorrectly. We conceive time as singular owing to the fact that all of our representations refer to a single consciousness. The concept of time is a priori in that, unlike a posteriori concepts, it is formed on the basis of reflection on inner, conscious states alone, whereas empirical concepts are formed on the basis of reflection on externally given objects. ${ }^{22}$ The various other properties of time, such as its homogeneity, continuity, and infinitude, are explicable from the properties of consciousness itself. Chelpanov believed that although he had shown time to be subjective, and therefore by his explicit definition psychologically a priori, it is also epistemologically a priori in the sense that time is a logical condition of cognition. Cognition, whether of the external or the internal world, is possible only as having a temporal form. In other words, time is a necessary condition for all cognition. ${ }^{23}$

\footnotetext{
${ }^{20}$ Of course, if psychology can provide such information, then the object of that study cannot be transcendental.

${ }^{21}$ See Kant I. Critique of Pure Reason / trans. Paul Guyer and Allen W. Wood. Cambridge: Cambridge University Press. 1997. C. 162 (A31-32/B47) [3].

${ }^{22}$ Chelpanov, in a 1903 essay «Психология и теория познания», wrote "Kant did not recognize space and time to be innate representations. Both are acquired by means of reflection on inner processes" [8, c. 116].

${ }^{23}$ Among the many lacunae in Chelpanov's position here was his collapsing of his own distinction between the psychological and the epistemological a priori. He did not show that time is a necessary con-
} 
The concept of causality, likewise for Chelpanov, is a priori. It certainly is not of empirical origin, since otherwise it would not be necessary and universal. Not being empirically derived, it cannot be proven empirically to be a law. The law of causality must be assumed in order for cognition to be possible. Remarkably, Chelpanov had little to say about its genesis in human consciousness. The same cannot be said concerning the concept of space. The manifold of sensation is not given in any particular order; it is simply given. As with temporality, spatial order is created and introduced into the manifold by consciousness itself.

Spatiality is created with the help of the synthetic activity of the mind, thanks to which there is a binding and an arranging of elements given from without into one definite whole. Therefore, we can say that spatial order or, what amounts to the same thing, extension in general is not affected by the external world, but is a product of the activity of our consciousness. In this sense, it represents an a priori element of our cognition [17, c. 729-730].

Chelpanov explicitly differed with Kant when the latter wrote that space is represented as an infinitely given magnitude. ${ }^{24}$ For the former, "it would hardly be correct simply to say that we represent space as infinite" [17, c. 734]. He added that we certainly cannot represent a particular extension without representing it as part of some other general and greater spatial container. In this sense, the representation of an infinite space is for us something potential. That is to say, we cannot represent some finite extension without implicitly recognizing as well the possibility of connecting additional extensions without end. Such is the sole correct sense of Kant's statement. Just as we can mentally extend a numerical series at will, so too can we do the same with spatial extensions. Our representation of space with the attributes Kant recognized is not given to us from externality. It is a subjective construction, and just as with temporality the formation of our representation of space is a matter for psychological investigation.

We, surely, can now fault Chelpanov for failing to distinguish our subjective conceptions of space and time from the space measured by meter sticks and the time measured by clocks. In particular, Chelpanov egregiously erred in concluding without argument that space and time were purely subjective with nothing corresponding to them in objectivity. Apart from possible objections, however, we could ask of Chelpanov how, if geometry is based on a psychologically generated space, there can be more than one geometry. It is to this topic that Chelpanov turned early in the following year.

dition of the cognition of externality. Moreover, if time is obtained subjectively, how can it be a condition for subjective events? Criticisms aside, Chelpanov, at least, believed he was upholding Kant's conception of time, albeit interpreted in a non-transcendental vein.

${ }^{24}$ See Kant I. Critique of Pure Reason / trans. Paul Guyer and Allen W. Wood. Cambridge: Cambridge University Press. 1997. C. 159 (A25/B41) [3]. 
Much of Chelpanov's long four-part essay, «Неогеометрия и ее значение для теории познания» (1902), is devoted to explaining what non-Euclidean geometry - "neo-geometry" in the parlance of Chelpanov's day - is and its philosophical importance as seen by others including, in particular, Helmholtz. Only at the end of his third installment and in the fourth did Chelpanov proceed to some of his own reflections on the topic. As in his previous essay, he held that the a priori is:

(1) that which is not obtained directly by the senses and

(2) a necessary presupposition of experience, understood as perception or knowledge. ${ }^{25}$

That which meets the first condition is psychologically a priori, whereas that which meets the second condition is epistemologically a priori. Chelpanov maintained there are some elements in our cognition that are a priori in both senses. But what is the status of geometric axioms?

Geometric axioms are assertions about the properties of spatial forms that, considered to be obviously true, are thought not to need formal proof and cannot be proven. In Kant's opinion, the apodicticity of geometric axioms is connected to their involvement with spatiality as a subjective form, i.e., as a form of consciousness. ${ }^{26}$ If our representation of space were different - so the charge goes - our geometry would be different. Euclidean geometry would, then, not describe the external world. If we would confine ourselves to the surface of a sphere, we would find that there are an infinite number of lines of the same length through the two points located at each end of the diameter of that sphere. The sum of the angles of a triangle drawn on a spherical surface is greater than $180^{\circ}$, etc. From this, someone might conclude that Euclidean geometry is based on one particular possible space and that the various nonEuclidean geometries are based on other "forms" of space. That we view the world in Euclidean terms shows that we make our choice of axioms based on experience, that geometry is empirical, and that its validity is, therefore, no greater than any physical science. Helmholtz, in an often cited paper from 1876, wrote, "But if we can imagine such spaces of other sorts, it cannot be maintained that the axioms of geometry are necessary consequences of an a priori transcendental form of intuition, as Kant thought" [20, c. 314]. In other words, Helmholtz held that neither geometry nor space is a priori in Kant's sense of that term.

Chelpanov, confronted with advances in mathematics, sought to disentangle our intuition of space from Euclidean geometry. Our representation of space is a form, and as such need not be conceived as having the specific features that would bind it to a particular set of geometric relations. Whereas in our (Euclidean) space a straight line is the shortest distance between two points, in another space the analo-

\footnotetext{
${ }^{25}$ Chelpanov in another psychology text wrote, "concepts that contain elements not obtained from sense experience are called a priori". Челпанов Г.И. Краткий повторный курс психологии. М.: «Сотр. шк.» А. Залесской. 1913. С. 133 [18].

26 Челпанов Г.И. Неогеометрия и ее значение для теории познания // Вопросы философии и психологии. 1902. Кн. 65. С. 1382 [19].
} 
gous spatial relations, e.g., on the surface of a pseudosphere, would possess other characteristics. ${ }^{27}$ Even three-dimensionality is not necessarily tied to our representation of space. "We can conceive [myslit'] a space that would retain its basic properties, e.g., externality, homogeneity, continuity, and that would yet not be threedimensional" [19, c. 1388]. However, if we cannot say with certainty that space has a particular character, we cannot say that our geometric axioms - or, for that matter, any other set - have absolute validity.

Chelpanov contended that some proponents of empiricism (e.g., Helmholtz) explain the correspondence between the Euclidean axioms and actual spatial relations by the alleged fact that the former arise under the direct affection of actual space. He replied that all geometrical forms are produced in consciousness and are idealizations. There are no truly straight lines in reality, only in our thoughts. If our geometrical formations were dependent on empirically given space, they would have an empirical character. That a geometry can be constructed with absolute consistency demonstrates its apriority, that its mental construction is not indebted to experience and to a particular space with certain features. The construction of internally consistent geometries shows that the concept of space is epistemologically a priori, a condition of cognition and of perception in general. Although we can acquire the content of geometric axioms from empirical observations of spatial relations, we need not do so. What is common to all geometries is that they all invoke an a priori conception of space. If we should seek more information about this conception, we must determine the characteristics of space that remain invariable throughout all geometries. While space is essentially dimensional, as already mentioned, it need not be three-dimensional. The other essential properties of space - exteriority, homogeneity, and continuity - are ideal and necessary, since space is a form of thought. "If we were to strip space of the property of exteriority, it would cease to be space. Whereas if we strip space, for example, of its threedimensionality or its zero curvature, space does not cease to be space but would only be another type of space" [19, c. 1408]. Chelpanov concluded his study, saying that although the development of intrinsically consistent non-Euclidean geometries is commonly thought as proving the non-empirical character of geometrical axioms, he believed they show that space must be considered a priori in the proper sense. What this proper sense is, though, is not entirely clear. We can be sure, though, that he saw his exercise as affirming $a$ Kantian conception of space.

Chelpanov also published a two-part contribution to the popular journal Мир божий during the same time period as his long essay on non-Euclidean geometry. This piece, «Эволюционный и критический метод в теории познания» (1902), set out to contrast the naturalistic approach of Herbert Spencer to Kant's Critical method. Although it sheds little, if any, additional light on Chelpanov's philosophical

\footnotetext{
${ }^{27}$ The obvious objection here is that there is no dispute as to the logical admissibility of other geometric relations. The issue, instead, concerns our representation of space. Do we intuit space as Euclidean? Can we mentally picture a straight line as not being the shortest distance between two points?
} 
stance, it does demonstrate his growing realization of a distinction between the naturalistically considered psychological a priori and the transcendental a priori. Now, more forcefully than previously, he found Kant's theory of cognition as having nothing to do with the origin of the a priori forms of scientific consciousness. Kant's concern is with epistemology, unlike Spencer whose interest was with the genesis and development of some concept. Epistemology accepts a scientific concept, such as causality, and asks whether and to what extent it can justifiably be utilized. Psychology, which was Spencer's concern, on the other hand, has no interest in justification. No doubt Kant recognized that the a priori forms and categories of cognition had a history, but this was of no interest to him. ${ }^{28}$

It is quite regrettable that Chelpanov, for the most part, did not provide a basis by which we could state with confidence his own attitude toward what he outlined in such simple and clear language. He stated that three elements are necessary for cognition: (1) sensations simpliciter; (2) the forms of space and time; and (3) categories, which are synthesizing forms. ${ }^{29}$ While we can clearly see Kant behind this assertion, was this Chelpanov's view as well? No unequivocal answer is given. Yet, he gave every indication further on in his discussion that he accepted the Kantian schema just mentioned. Some who accept a naturalistic interpretation of Kant may argue that owing to changes in our physiological conditions, the exact nature of our a priori forms may change in direct response. Chelpanov found such a view to be wrong in that it presupposes a direct and naturalistic connection between physiological processes and our epistemological forms of consciousness. In the absence of evidence in support of this presupposition, "we cannot draw any conclusions concerning the variability of the forms of consciousness" [21, c. 113]. ${ }^{30}$ Whereas the manner of perceiving space and time may vary, that we conceive space and time as forms does not change.

\section{A Defense of Transcendental Realism}

Chelpanov published and defended as a doctoral dissertation in 1904 his promised work on our perception of space considered philosophically. In it, he reaffirmed yet again that our conception of space is a priori, ideal, and a subjective form of cognition. He devoted considerable attention in it to Kant's theory and in fact repeated much that he had stated in his two-part article from the previous year. Indeed, a large portion of the dissertation itself was taken over from the extensive articles he had previously published and which we have already examined. ${ }^{31}$ For this reason we need not belabor

\footnotetext{
28 Челпанов Г.И. Эволюционный и критический метод в теории познания // Мир Божий. 1902. № 8. С. 98 [21].

29 Челпанов Г.И. Эволюционный и критический метод в теории познания // Мир Божий.. С. 101.

${ }^{30}$ In this matter, he explicitly invoked the neo-Kantian Friedrich Paulsen in support of his position.

${ }^{31}$ The ideas presented in the dissertation's Chapter 3 stem from [15]; Chapter 4 is largely a reprint of [8]; the ideas in Chapter 5 stem from Chelpanov [21]; most of Chapter 6 is a reprint with insignificant changes from Chelpanov [16] and [17]; and, finally, Chapter 7 is largely a reprint of [19].
} 
our probe into it. Let us look, though, at some of Chelpanov's discussions that are new or at least amplify what we have already seen. For example, in his dissertation, he explicitly contrasted many of the positions he had supported in the past to those offered by others including contemporaries. One instance of this concerns Ivan Lapshin, who, in the «Предисловие» (1896) to his Russian translation of William James's Psychology Briefer Course, wrote that the psychological theory of the underived nature of the $a$ priori is indistinguishable from the epistemological view of the same. Lapshin contended that those who uphold Kant's epistemological view logically must also hold the psychological view. ${ }^{32}$ As we would expect from what we have seen, Chelpanov disagreed. For him, the aim of psychology in this matter is to show that extension cannot be derived from unextended elements, whereas the epistemological enterprise is to show the impossibility of thinking of unextended objects. ${ }^{33}$ The viewpoints of psychology and epistemology also differ with respect to the concept of necessity. Necessity in psychology is a statement concerning the constant conjunction of representations, whereas in epistemology - Kant's standpoint - necessity has an objective character. The objects of cognition are seen as bearers of some necessary character. In Kant's case, this necessity is introduced by cognition itself..$^{34}$

We have seen that to a surprising degree Chelpanov agreed with much of Kant with respect to space and time. A question that remains and that has haunted Kantscholarship since its first days is whether the acceptance of Kant's arguments concerning space and time necessarily entail his conclusion that space and time are nothing other than the forms of appearances, i.e., transcendental idealism. ${ }^{35}$ Is it possible to accept Kant's arguments and yet hold that although our representations of space and time are necessarily subjective, there is still something objective, something independent of us, that corresponds to them? This is the topic of the final chapter in his dissertation, Chapter 8.

There are some, Chelpanov charged, who reject the existence of things independent of consciousness. One such idealist, to use Chelpanov's terminology, was Berkeley, who had to turn to God, who interacts constantly with human individuals to provide us with representations. If we decline to proceed down such a road, we have no way to explain specific representations that arise in the human mind and of-

\footnotetext{
32 Лапшин Иван И. Философское значение психологических воззрений Джемса. Джемс, Уилльям. Психология. (Text Book of Psychology) / пер. И. И. Лапшин. СПб.: Тип. Сойкина. 1896. С. 25 [22].

33 Челпанов Г.И. Проблема восприятия пространства в связи с учением об априорности и рождении. Часть II: Представление пространства с точки зрения гносеологии. К.: Тип. Кушнерев. 1904. C. $122 \mathrm{n}[23]$.

34 Там же. С. 128. Ср. Челпанов Г.И. 1903. Психология и теория познания // Вопросы философии и психологии. 1903. Кн. 67, С. 178 [8].

${ }^{35}$ Kant I. Critique of Pure Reason / trans. Paul Guyer and Allen W. Wood. Cambridge: Cambridge University Press. 1997. C. 159 (A26/B42), 163 (A33/B49 [3]).
} 
ten enough contrary to our wishes without conceding the existence of a transcendent or at least a transsubjective world..$^{36}$

Chelpanov recognized as Kant's response to empirical idealism that things do exist independently of us, but these things provide only the material, or manifold, for sensations whereas time and space come from our cognitive faculty as forms. The cause of our sensations, then, is, in Chelpanov's understanding of Kant, the thing in itself, which exists independently of our representations. Since the forms of space, time, and causality are imposed by consciousness onto the material provided by things, these things themselves can have none of those forms. Thus, Chelpanov alleged that Kant and his followers err in recognizing "transcendent" things in themselves as the cause of sensations:

The recognition of something transcendent, i.e., something existing independently of our consciousness, to which the forms of our mind cannot be applied but which nevertheless must exert an affection on our consciousness, seems quite incomprehensible. ... This is why Kantians, in order to retain Kant's point of view, i.e., in order to recognize transcendent 'things in themselves' as the cause of sensations and at the same time explain the origin of our cognition, introduce the concept of an "empirical affection" in contrast to «transcendent» affection $[23$, c. $399-400] .{ }^{37}$

Thus, based on these words alone we see that Chelpanov set himself apart from the "Kantians". He did not see himself in 1904 as a Kantian transcendental idealist. This does not mean, however, that Chelpanov must be stricken from the ranks of neoKantianism. Chelpanov, next, launched into an exposition of the "double affection" theory, which proposes to eliminate the apparent contradiction concerning how a thing in itself can "cause" my empirical representations by having things in themselves causally affect the transcendental ego (or "I") and empirical objects causally affect the empirical subject. We need not pursue this issue further, for Chelpanov again shied away from controversy proclaiming he will not attempt to adjudicate the merits of the theory. ${ }^{38}$

\footnotetext{
36 Челпанов Г.И. Проблема восприятия пространства в связи с учением об априорности и рождении. Часть II: Представление пространства с точки зрения гносеологии. К.: Тип. Кушнерев. 1904. C. 397. Such a stand is quite compatible with Kant's own form of transcendental idealism as against Berkeley's empirical idealism. In Kant's eyes, transcendental idealism is an empirical realism, whereas Berkeley's empirical idealism is a transcendental realism. For more on this, see [3, c. 426 (A369)].

${ }^{37}$ As his very terminology indicates, Chelpanov confused the transcendent with the transcendental. In doing so, he fell victim to an illusion utilizing the category of causality beyond its limited immanent use. See [3, c. 385 (A295-296/B352)].

${ }^{38}$ Chelpanov did not shy away, though, from writing that in any case Kant himself did not hold to any conception of an epistemic noumenal affection, whether it be encased in a theory of double affection or not. Kant wrote only of "causality through freedom". Челпанов Г.И. Проблема восприятия пространства в связи с учением об априорности и рождении. Часть II: Представление пространства с точки зрения гносеологии. К.: Тип. Кушнерев. 1904. С. 402 [23].
} 
Chelpanov found that problems regarding the existence of the thing in itself in no way are resolved with Kant's "Refutation of Idealism", as found in the second edition of the first Critique. Whereas for Chelpanov the true correlate of my representations and intuitions should be actual things, things in themselves, ${ }^{39}$ Kant, in the "Refutation" confused a proof for the existence of things in themselves with one for the existence of a thing in space. Although he refuted the "problematic idealism" of Descartes, he should have undertaken to refute idealism in general. If his interest were sincere, he would have shown that there are things in themselves independent of our representations of them, which are responsible for things in space. Kant's "error in this case is obvious" [23, c. 403].

No doubt some neo-Kantians were - and are - aware of Kant's problems and of his failure to prove the existence of independent things in themselves. In order to uphold Kant's overall position while avoiding its problems, they re-interpret the thing in itself not as a distinct entity existing independently of cognition (under the "two-worlds interpretation"), but as an asymptotic, limiting concept, the result of lawful sensible connections produced by consciousness. In their eyes, the synthetic activity of consciousness itself creates its own objects. ${ }^{40}$ Chelpanov commented that on this basis these neo-Kantians find they have no need to admit the existence of some transsubjective world. Chelpanov found such a position insupportable both philosophically as well as based on Kant's own texts. He affirmed, on the contrary, that we must recognize the existence of a transcendent reality that provides the material of sensation. We must also account for why in a particular instance causality is invoked and not some other category or none at all. That causality is invoked on some occasions and not on others cannot be explained relying solely on subjective factors. If the connections of sensations were due exclusively to subjective factors, there would be no compulsory connections and certainly no consistent agreement between people. "If we did not recognize the existence of a transsubjective reality with its specific law-governed regularity, it would be impossible to understand why we must apply in this or that case this or that specific category" [23, c. 407-408]. Chelpanov saw this as a proof, a transcendental proof, of the existence of a transsubjective world. However, this by no means entailed the elimination of a transcendental apperception connecting representations.$^{41}$ Our cognition is the product of an interaction between the regularity of things and the regularity that consciousness introduces into things. The thing in itself is a correlate of the unity of apperception. Chelpanov likened the application of categories to the perception of colors, which is also not entirely subjective. I see the rose as red owing, for one thing, to some complex set of chemicals in the object, etc., but also owing to something in my visual apparatus that

\footnotetext{
${ }^{39}$ Chelpanov provided no textual support in Kant for this claim. Instead, he referred the reader to secondary sources, such as Zeller, Volkert, and Riehl.

${ }^{40}$ Chelpanov in this discussion mentioned [24] and [25] in a footnote, but surprisingly not [26].

${ }^{41}$ Chelpanov's imprecision here and elsewhere should not blind us to the essential Kantian point he is making here.
} 
regularly responds to the reception of the same wavelength of light from the rose. One or the other could conceivably not be regular, in which case I would not see that same rose as consistently red. ${ }^{42}$

Chelpanov read Kant along these lines and deemed him to be correct. The former wrote, "For me, it is indubitable that Kant must have recognized the existence of an objective foundation of space" [23, c. 411]. Therefore, space is the product of the interaction of two factors. On the one hand, we have consciousness with certain properties, and on the other hand, we have an objective foundation in the intentional object with definite properties. Conceivably, this objective foundation in the object is not itself space, but only an analogue of space comparable to what is responsible for us seeing something as a particular color. Chelpanov added that we must remain ultimately agnostic in this. All we can say is that our representation of space corresponds - much like a symbol - to something existing in exteriority. He denominated this position as "transcendental realism" as against "transcendental idealism", which takes space to be something merely subjective. In transcendental idealism, there is no accounting for the regular order of a particular given spatial object. There is no explanation why you see my particular books arranged in the same order that I do. "Therefore, we must recognize the existence of an objective correlate, of a certain objective foundation of space, in relation to which our concept of space is, in a certain sense, a reflection" [23, c. 415].

Transcendental realism, or to use the expression he evidently preferred "ideal realism", owing to its allowance for ideal elements within a general realist ontology, was Chelpanov's own stand. But he also believed it is fully consistent with and can be found in Kant's texts. Although Kant wrote that space and time are subjective forms, Chelpanov believed this must not be understood as implying that they are found in consciousness in advance [zaranee] of the sensible manifold. He absolutely rejected the position that space is exclusively subjective. ${ }^{43}$ Were he to do so would mean transgressing the bounds of empirical reality. He did not concern himself with what transcendent reality is. He recognized its existence and therefore could not deny the objective foundation of space. Such are the positions concerning space that Chelpanov believed Kant espoused and that Chelpanov also held in 1904.

\section{A Neo-Kantian malgré lui}

Sergej Trubeckoj, a well-regarded professor of philosophy at Moscow University, suffered a fatal stroke while waiting for a meeting with the minister of education

\footnotetext{
${ }^{42}$ Although this particular example of the color red is taken from Kant, Chelpanov does mention sound and color. He was especially indebted in this matter to Riehl, whose discussion is quite similar. See Riehl Alois. Der philosophische Kriticismus und seine Bedeutung für die positive Wisenschaft. Zweiter Band, Erster Theil // Leipzig: Wilhelm Engelmann. 1879. C. 50-65 [27].

43 "Could Kant look on space as something exclusively subjective? It seems to me absolutely not. Kant thought that the existence of things in space is immediately obvious. This required no proof". [23, c. 411n].
} 
in St. Petersburg in September 1905. His sudden death created a vacancy at the University. The academic committee there in the following year invited Chelpanov to fill the opening, finding him to be the uniquely qualified candidate for the professorship in philosophy and psychology. ${ }^{44}$ Chelpanov took up his duties in Moscow in 1907 and as customary gave an inaugural lecture in September entitled «Об отношении психологии к философии» (1907). Unfortunately for us, the talk covered little new ground. It largely summarized his view that each discipline needed the other, a heated topic at the time.

In the years subsequent to his appointment at Moscow University, Chelpanov devoted himself far more to psychology and in particular to the promotion of experimental psychology than to philosophy. His treatise in 1908 "On the Mind of Animals" examined to what extent animals can be held to have minds comparable to human minds. Do they have mental concepts as we do? Do they have faculties of reason and understanding? Regrettably, Chelpanov failed to address these questions in a manner that would allow us to draw any additional conclusions that would comfortably allow us to characterize him as a neo-Kantian. Kant is not so much as mentioned in the published papers stemming from this line of inquiry. And also disappointingly, the issue of whether animals perceive space and/or time as we do received no attention.

In 1909, Chelpanov published a defense of experimental psychology vis-à-vis the more traditional reliance on introspection as a psychological technique. He defended both objective and subjective methods, finding that psychology in general will always rest on self-observation even while relying on objective techniques. This piece hardly dealt with the issues confronting us here, but it remains interesting to see Chelpanov's acknowledgement of Husserl at this early date even though that name does not figure prominently. Evidently consumed with his new duties, his family, and a newly created experimental psychology laboratory, Chelpanov devoted little time to pure philosophy. Psychology, after all, was his chief interest. However, let us look at two works, both of which went through multiple editions during his lifetime.

Chelpanov's large, sustained attack on materialism, «Мозг и душа» (1906), was based originally on public lectures presented in Kiev in 1898-1899. The first edition of the collected lectures appeared in 1900 and the last edition, the sixth, appeared in 1918. Its masterfully clear and thorough critique of materialism notwithstanding, much of its concern falls outside the bounds of our topic here. However, Chelpanov did turn in one of the book's chapters to space and in another to time. Inasmuch as he reiterated his stand without substantial modification over the various editions and in more than one publication, we can conclude that his statements represented his settled conviction. As in his dissertation, Chelpanov likened our representations of space and time to our sensation of sound and our representation of color. Indeed, they

\footnotetext{
${ }^{44}$ Рубцов В.В., Серова О.Е., Гусева Е.П. К 150-летию со дня рождения Георгия Ивановича Челпанова // Культурно-историческая психология. 2012. № 1. С. 98 [5]. The elation which Chelpanov naturally would have felt with the news of the appointment was tempered if not made bittersweet by the unexpected death of his wife that same year leaving him with three young children.
} 
are completely analogous, and like them space and time have a subjective character. ${ }^{45}$ Just as other earthly creatures may conceive colors and hear sounds differently than we do, the very possibility of the construction of non-Euclidean geometries demonstrates that at least with regard to space, it may have different properties than we represent it as having in everyday life. That we cannot represent space in some manner different than we do is itself proof that our representation of it is connected in the strongest way possible with our psycho-physical organization.

If our organization conditions our representation of space, it is subjective in the sense in which the sensation of a color or a sound is subjective. Consequently, we must not think that our space is absolute, an existence independent of our subject. ... In this sense, our space exists only for us, only for our subject. For another consciousness our space would perhaps not exist [28, c. 208; 29, c. 185].

And Chelpanov again reiterated that our representations of space and time, while subjective, certainly correspond to something in the objective world just as colors do in the perceived object. This "something", though, is quite different from our mental picture of it. ${ }^{46}$ Time, as we represent it, exists only in our consciousness. Objectively, i.e., outside the human consciousness, there is no time. If the process of transmission by which the objective world conveys to us our representation of time were to cease functioning, time would be eliminated. In such a fairytale world where all living beings otherwise cognizant of time were fast asleep, time would not exist.

As with «Мозг и душа», Chelpanov reworked his basic text «Введение в философию» (1916) numerous times during his professorial career. Indeed, it went through seven editions - the last appearing in 1918 - in his lifetime and offered wide-ranging presentations in remarkably simple language. Chelpanov in this «Введение» reiterated yet again his stand that our concepts of space and time do not correspond to an objective something such that our concepts would be mere copies or reflections of that something. Therefore, our concepts are products of the functioning of our consciousness. Consciousness creates those concepts. Although we conceive space to be infinite, it, being merely subjective, is not objectively so. ${ }^{47}$ Chelpanov also added the "form" of causality to those of space and time. Possibly leading the reader astray, however, he began mentioning Kant's name in conjunction with the position that other forms, such as substance, are created in consciousness by its functioning. In this manner, whether what Chelpanov ascribed to Kant was also his own

\footnotetext{
45 Челпанов Г.И. Мозг и душа. Критика материализма и очерк современных учений о душе. К.: B.A. Просяниченко. 1906. С. 197 [28]. Also Челпанов Г.И. Мозг и душа. Критика материализма и очерк современных учений о душе. М.: Кушнерев. 1912. С. 176 [29].

${ }^{46}$ This and what Chelpanov further said regarding time can be discussed ad nauseam with respect to Kant. Briefly, Kant at one time held that colors are not objective qualities of intuited bodies. Cm.: [3, c. 161 (A28)]. He then apparently reversed himself in the second edition of the first Critique, saying "the predicates of appearance can be attributed to the object in itself". Там же. C. 190 (B69). There are many other facets to the issue Chelpanov raised. What certainly appears to be indubitable is that Kant objected to comparing the ideality of space with "things like colors, taste, etc.". Там же. C. 161 (A29/B45).

47 Челпанов Г.И. Введение в философию. М.: Подсказка. В.В. Думнов. 1916. С. 34 [30].
} 
position is ambiguous. What he did clearly state is that there are no innate ideas as such. "There can only be innate capabilities to form these or those ideas" [30, c. 53]. Nonetheless, Chelpanov insisted that this is not to be understood psychologically. He was making no claim about temporal origin, since such a concern would presuppose temporality. Rather, epistemology accepts a concept as it is already found in science and seeks to establish its attributes with the aim of determining why and how it is applied in experience.

Chelpanov also reiterated his position that the forms of consciousness, while $a$ priori, are symbolic of something in objectivity much like our representation of a color is symbolic of a certain wavelength of light. We see from this that there is an enormous difference between a representation and that which evokes it. But we can conclude that there are things in themselves, though how they "truly" are must remain beyond our cognitive ability. On the other hand, such talk appears to invoke causality beyond the bounds of its legitimate use - or at least in Kant's scheme it does. Chelpanov recognized the issue but apparently preferred to remain agnostic. He recognized that some have proposed a "double affection", but he stated that Kant would hardly have found that to be satisfactory. Whereas Kant did write of another causality, a causality through freedom, its applicability is only to human action. ${ }^{48}$ In the end, Chelpanov claimed agreement with Windelband that the cognized object is a totality of sensations connected by certain rules. ${ }^{49}$ Further inquiry is essentially pointless, for it would involve exiting the theory of cognition and venturing into metaphysics. We must, in the final analysis, limit ourselves to saying that our sensations and representations are indicative of transcendent somethings, which we can never know. These "somethings" in some manner induce our consciousness to apply particular a priori categories or forms in a particular instance and not in another. Such a standpoint, Chelpanov's standpoint, he now called "critical realism" ${ }^{50}$ In his 1913 psychology textbook referenced above, he elaborated slightly, writing that our certainty in the constancy of elementary physical laws remains steadfast even though this stand itself remains unproven. In fact, no fac-

\footnotetext{
${ }^{48}$ According to the most technical treatment of "double affection", transcendent things in themselves affect the transcendent consciousness in itself while correspondingly empirical things affect my empirical consciousness. The development of this position took place more recently than Chelpanov's work, but he knew of its early formulations. Seе Челпанов Г.И. Введение в философию. М.: Подсказка. В.В. Думнов. 1916. С. 86-87 [30].

49 Там же. С. 118.

50 Там же. C. 120. There is no indication in Chelpanov's numerous texts that he essentially distinguished the various designations he used to characterize his own overall position. Why Chelpanov employed one particular expression at one time and another expression at another time is unclear. Certainly, the expression "critical realism" had already been attached to the positions of several philosophers whom he evidently held in high regard such as Riehl, who in effect labeled his stance as a "critical realism". See Riehl Alois. Der philosophische Kriticismus und seine Bedeutung für die positive Wisenschaft. Zweiter Band, Zweiter Theil. Leipzig: Wilhelm Engelmann. 1887. C. 174 [31]; Also Riehl Alois. Introduction to the Theory of Science and Metaphysics. London: Kegan Paul, Trench, Trübner, \& Co. 1894. C. 165 [32]. In particular, Wilhelm Wundt, to whom Chelpanov often positively referred, had used the expression "critical realism" in the very title of his serialized article "Über naiven und kritischen Realismus", which started to appear in 1896.
} 
tual evidence could disprove the law of causality. This, to Chelpanov's mind, demonstrated that the causal law is a presupposition, i.e., a transcendental a priori condition, of cognition. Furthermore, our apprehension of the incessant change of appearances given to cognition would be inconceivable if we did not presuppose the persistence of some unalterable thing grounding these appearances. This ground is called "substance". In other words, substances are a necessary presupposition of cognition. ${ }^{51}$ Chelpanov, in this manner, reiterated Kantian transcendental arguments for the categories of causality and substance, and thereby again demonstrated his stand that these two key categories are to be understood as Kant did.

Chelpanov did provide summaries of various ethical theories such as utilitarianism and the then-popular views of Spencer and Schopenhauer. These are little more than perfunctory expositions as required in an introductory survey text. However, he realized that any talk of morality required some account of responsibility and that in turn leads to the perennial issue of free will. Being, above all, a psychologist, Chelpanov recognized that human actions are not totally arbitrary. Not only are many of our actions determined by some external factor, but we must take into account also social causes. Our particular will is very much shaped not just by the environment, but by our past which formed our character. In general, there is a reason we act as we do. Therefore, in a sense all of our actions are caused and, therefore, necessary in the sense of being law-governed. Yet, even though our actions are caused we are responsible for them. Chelpanov recognized the unoriginality of this conclusion. Such diverse thinkers as Kant and Mill recognized it, but so too did Paulsen and Wundt. "It is precisely the feeling of responsibility that is the cause of the fact that we consider the will to be free" [30, c. 473]. We routinely interpret this human feeling as meaning that externality is not the decisive factor in our choice of action. We decide on a course of action through a realization of what kind of individual we are, how we understand our own character, which requires a self-consciousness including an ability to connect the present with the past. We see from this why animals cannot be held responsible for their actions. Lacking self-consciousness, they cannot ascribe freedom to themselves. ${ }^{52}$ Only human beings in the natural world are ethical beings.

In the final years of the Imperial Russian regime, Chelpanov devoted little attention to purely philosophical problems. If we except revisions to his introductory text and a few reviews, his writings at the time, though still significant in number, belonged to psychology and, to a lesser degree, pedagogy. The psychological institute that Chelpanov created with generous funds from a non-academic source and directed until November 1923 was expropriated from him as was his position at Moscow University. Chelpanov valiantly attempted to defend non-partisan scholarship against official assaults to no avail, of course. During a significant portion of that decade, he was attached to the Государственная академия художественных наук (ГАХН), where he was able to carry out some psychological investigations.

\footnotetext{
51 Челпанов Г.И. Краткий повторный курс психологии. М.: «Сотр. шк.» А. Залесской. 1913. С. 135 [18]. См. [3, с. 300 (A182/B225-226)].

52 Челпанов Г.И. Введение в философию. М.: Подсказка. В. В. Думнов. 1916. С. 474-476 [30].
} 
However, in 1930 he and the remaining staff were let go with the liquidation of $\Gamma \mathrm{AXH}$, and Chelpanov was forced into retirement. ${ }^{53}$

In light of the exposition above, the question still lingers: Was Chelpanov a neo-Kantian? What is clear is that he never referred to himself in print as a neoKantian. Indeed, he distinctly distanced himself from those routinely characterized as "neo-Kantians" in his writings. In his own Введение в философию, he called F.A. Lange, the celebrated author of the three-volume Geschichte des Materialismus, a "typical representative of neo-Kantianism". ${ }^{44}$ The same characterization can also be found in Chelpanov's earlier book «O современных философских направлениях» (1902), in which he also wrote that neo-Kantianism arose in the 1860s and represented a third form of positivism. ${ }^{55}$ One may conclude from this that Chelpanov distanced himself from neo-Kantianism owing to a difference concerning the viability of metaphysics as a philosophical discipline. However, he also listed Cohen, Natorp, Windelband, Liebmann, and even Riehl as representatives of neo-Kantianism, although these figures espoused quite different understandings of that general direction. ${ }^{56}$ Chelpanov paid the greatest homage, based on references and direct textual expressions of agreement, to Wilhelm Wundt and Friedrich Paulsen, the latter commonly labelled a neo-Kantian. ${ }^{57}$

A definitive determination of Chelpanov's philosophy vis-à-vis neoKantianism is impossible, particularly in light of his many inconclusive statements. On the one hand, he stated that the "inductive metaphysics" of Wundt and Paulsen represented the "latest word of contemporary philosophy". To be sure, Chelpanov admitted that Wundt's philosophy contained contradictions on specific points, but

\footnotetext{
${ }^{53}$ Although arguably more information on Chelpanov as an individual and his family is not germane to our philosophical concerns here, the family story is filled with loss and tragedy. His older brother Vasilij, to whom he was close in his youth, was executed in 1920 as a representative of the bourgeoisie. The closing of GAKhN left Chelpanov in a precarious financial position. In 1930, his daughter Natal'ja, who had married a French diplomatic attaché, was forbidden entry into the Soviet Union, and Chelpanov never saw her again. In 1933, another daughter, Tat'jana, died. In 1935 his granddaughter Marina, the daughter of his son Aleksandr, also died, followed shortly afterward in the same year by the execution of Aleksandr on the fabricated and preposterous charge of conspiring for Germany against the Soviet government. Chelpanov himself, by this time in rather poor physical condition, was not informed. This and a great deal more biographical information, including the family tree, can be found in Бочарова Э.Б., Боробьев В.С. Малоизвестные страны жизни Г. И. Челпанова: к 150-летию со дня рождения // Теоретическая и экспериментальная психология. 2012. Том 5, вып. 3 [33].

54 Челпанов Г.И. Введение в философию. М.: Подсказка. В. В. Думнов. 1916. С. 271 [30].

55 Челпанов Г.И. О современных философских направлениях / под ред. Густав Шпет. К.: Тип. Петр Барский. 1902. С. 59 [2].

56 Челпанов Г.И. Введение в философию. М.: Подсказка. В. В. Думнов. 1916. С. 283 [30]. In а logic text from his Kiev years, he wrote, "I affirm that from the logical point of view we have no right to deny the possibility of metaphysics, i.e., the science of super-experiential cognition. ... I want to show that cognition in both metaphysics and science is subject to the same laws and that truth is the same in both science and metaphysics. There certainly can be doubt only concerning the degree of validity of the cognitions attained by them" [34, c. 157].
}

${ }^{57}$ Beiser Frederick C. The Genesis of Neo-Kantianism, 1796-1880. Oxford: Oxford University Press. 2014. C. 2 [58]. 
these were unimportant in comparison with the method employed, viz., that Wundt reconciled natural science with metaphysics thereby moderating the pretensions of both. ${ }^{58}$ On the other hand, we saw that he characterized his position as a "critical realism". Moreover, we saw a repetition of key points in a number of his writings that qualify him as a realist neo-Kantian. True, even in his own day, Chelpanov's contemporaries struggled to attach a consistent label to his position. Sergej A. Askol'dov (1871-1945), who later taught at St. Petersburg University, saw Chelpanov's doctoral work as representative of a very qualified form of Kantian Criticism, certainly not of an orthodox form. On the other hand, Chelpanov, in Askol'dov's estimation, held views incompatible with the basic doctrines and most important conclusions of Kantianism. Although Chelpanov allowed for Kantian a priori conditions of cognition and thus adhering to this extent to Kantianism - he also claimed that things in themselves, despite being unknowable, affect in some manner our experience and, in turn, our cognition. ${ }^{59}$ Thus, it is impossible for him to say that things in themselves are uncognizable. ${ }^{60}$ Askol'dov added that if Kant had accepted what Chelpanov allowed, all of Kant's conclusions in his first Critique would be imperiled.

Others with a greater familiarity with contemporary German philosophy and neo-Kantianism, in particular, were not so quick to expel Chelpanov from the neoKantian camp. We should recall, for example, that the principal basis for Askol'dov's rejection of characterizing Chelpanov as a neo-Kantian was the latter's belief in noumenal affection. Yet in addition to Paulsen, Alois Riehl, as we saw, unquestionably held a realist view, writing that "space and time are concepts that have their empirical and real basis in the manifold of sensations, their ideal foundation in the logical capacities of our mind" [27, c. 107]. If anything, Chelpanov, with his affirmation of the uncognizability of things in themselves, was even more of a Kantian than was Riehl, who rejected their uncognizability. Also unlike Riehl, for whom the existence of external objects was a matter of immediate knowledge, something that needed no philosophical proof, for Chelpanov the need to accept noumenal affection in order to account for appearances counted as a philosophical proof of that existence. ${ }^{61}$ Finally, for the last word on this topic, we turn to Boris Jakovenko, who in an extended essay from 1922 wrote, "Among the Kantians should also be included G.I. Chelpanov, who in his vast epistemological investigations devoted to the problem of space, attempted to provide a grounding for Critical Philosophy in the spirit of transcendental realism" [37, c. 807]. ${ }^{62}$

\footnotetext{
58 Челпанов Г.И. О современных философских направлениях / под ред. Густав Шпет. К.: Тип. Петр Барский. 1902. С. 91, 106 [2].

${ }^{59}$ Аскольдов С.А. Теории новейшаго критицизма. (По поводу двух книг) // Вопросы философии и психологии. 1904. Кн. 74. С. 520-549 [36].

${ }^{60}$ Там же. С. 546.

${ }^{61}$ Riehl Alois. Der philosophische Kriticismus und seine Bedeutung für die positive Wisenschaft. Zweiter Band, Erster Theil // Leipzig: Wilhelm Engelmann. 1879. C. 186, 18.

${ }^{62}$ For the very reason that Askol'dov gave, few would place Chelpanov among the "Kantians". Thus, Pustarnakov is correct in writing that Chelpanov cannot be classified as a Kantian and that Chelpanov, unlike Kant, held metaphysics could be a science "connected with the inductive conclusions of the concrete sciences" [38, c. 683]. He is wrong, though, in not recognizing the common elements between
} 
Chelpanov was a quiet neo-Kantian. That some denied him that label had much to do with their own narrower understanding of the term.

\section{Список литературы}

1.Челпанов Г.И. 1911. Памяти проф. Н.Я. Грот // Николая Яковлевича Грот в очерках, воспоминаниях и письмах. СПб.: Тип. Кушнерев, 1911. С. 185-196.

2. Челпанов Г.И. О современных философских направлениях / под ред. Густав Шпет. К.: Тип. Петр Барский, 1902. 108 с.

3. Kant I. Critique of Pure Reason / trans. Paul Guyer and Allen W. Wood. Cambridge: Cambridge University Press, $1997.785 \mathrm{~s}$.

4. Челпанов Э.И. О природе времени // Вопросы философии и психологии. 1893. Кн. 19. С. 36-54.

5. Рубцов В.В., Серова О.Е., Гусева Е.П. К 150 -летию со дня рождения Георгия Ивановича Челпанова // Культурно-историческая психология. 2012. № 1. С. 92-109.

6. Челпанов Е.И. 1891. Гельмгольц как философ и психолог // Вопросы философии и психологии. 1891. Кн. 10. С. 41-51.

7. Челпанов Г.И. Проблема восприятия пространства в связи с учением об априорности и врожденности. Часть I: Представление пространства с точки зрения психологии. К.: Типография Кушнерев, 1896. 387 с.

8. Челпанов Г.И. 1903. Психология и теория познания // Вопросы философии и психологии. 1903. Кн. 66. С. 97-124; Кн. 67: С. 167-189.

9. Kant I. Theoretical Philosophy after 1781. Cambridge: Cambridge University Press, 2002. $530 \mathrm{~s}$.

10. Kant I. Theoretical Philosophy, 1755-1770 / trans. and ed. David Walford and Ralf Meerbote. Cambridge: Cambridge University Press, 1992. 543 s.

11. Stumpf C. Über den psychologischen Ursprung der Raumvorstellung. Leipzig: Hirzel, 1873. $324 \mathrm{~s}$.

12. Грот Н.Я. 1896. [Рецензия] Челпанов. Проблема восприятия пространства в связи с учением об априорности и рожденности // Вопросы философии и психологии. 1896. Кн. 35. С. 651-656.

13. Челпанов Г.И. 1897. К вопросу о восприятии пространства // Вопросы философии и психологии. 1897. Кн. 37. С. 276-287.

14. Челпанов Г.И. 1897. О свободе воли // Мир Божий. 1897. № 11. С. 2-24; № 12. С. 42-65.

15. Челпанов Г.И. Философия Канта. Статья 1-я (Теоретическая философия) // Мир Божий. 1901. № 3. С. 23 ; № 4. С. 165-187; № 5. С. 55-80.

16. Челпанов Г.И. Об априорных элементах познания (Понятия числа) // Вопросы философии и психологии. 1901. Кн. 59. С. 529-559.

17. Челпанов Г.И. Об априорных элементах познания (Понятия времени, причинности, пространства) // Вопросы философии и психологии. 1901. Кн. 60. С. 699-747.

18. Челпанов Г.И. Краткий повторный курс психологии. М.: «Сотр. шк.» А. Залесской, 1913. 214 с.

19. Челпанов Г.И. Неогеометрия и ее значение для теории познания // Вопросы философии и психологии. 1902. Кн. 65. С. 1379-1408.

20. Helmholtz Hermann. 1876. The Origin and Meaning of Geometrical Axioms. Mind. 3(1). C. $301-321$.

21. Челпанов Г.И. Эволюционный и критический метод в теории познания // Мир Божий. 1902. № 8. С. 94-117.

22. Лапшин Иван И. Философское значение психологических воззрений Джемса. Джемс, Уилльям. Психология. (Text Book of Psychology) / пер. И.И. Лапшин. СПб.: Тип. Сойкина, 1896. C. 1-35.

23. Челпанов Г.И. Проблема восприятия пространства в связи с учением об априорности и рождении. Часть II: Представление пространства с точки зрения гносеологии. К.: Тип. Кушнерев, 1904. $429 \mathrm{c}$.

24. Cohen Hermann. Kants Begründung der Ethik. Berlin: Ferd. Dümmler, 1877. 328 s.

Chelpanov and Kant that allow us to characterize Chelpanov as a neo-Kantian, albeit one who shied away from overt statements of his philosophical convictions. 
25. Cohen Hermann. Kants Theorie der Erfahrung. Berlin: Ferd. Dümmler, 1885. $616 \mathrm{~s}$.

26. Cohen Hermann. Logik der reinen Erkenntniss. Berlin: Bruno Cassirer, 1902. $520 \mathrm{~s}$.

27. Riehl Alois. Der philosophische Kriticismus und seine Bedeutung für die positive Wisenschaft. Zweiter Band, Erster Theil // Leipzig: Wilhelm Engelmann, 1879. 292 s.

28. Челпанов Г.И. Мозг и душа. Критика материализма и очерк современных учений о душе. К.: В.А. Просяниченко, 1906. 366 с.

29. Челпанов Г.И. Мозг и душа. Критика материализма и очерк современных учений о душе. М.: Кушнерев, 1912. 319 с.

30. Челпанов Г.И. Введение в философию. М.: Подсказка. В.В. Думнов, 1916. 568 с.

31. Riehl Alois. Der philosophische Kriticismus und seine Bedeutung für die positive Wisenschaft. Zweiter Band, Zweiter Theil. Leipzig: Wilhelm Engelmann, 1887. 358 s.

32. Riehl Alois. Introduction to the Theory of Science and Metaphysics. London: Kegan Paul, Trench, Trübner, \& Co, 1894. $346 \mathrm{~s}$.

33. Бочарова Э.Б., Боробьев В.С. Малоизвестные страны жизни Г.И. Челпанова: к 150-летию со дня рождения // Теоретическая и экспериментальная психология. 2012. Т. 5, вып. 3. С. 81-102.

34. Челпанов Г.И. Курс лекций по логике. К.: Тип. И.И. Чоколова, 1901. 163 с.

35. Beiser Frederick C. The Genesis of Neo-Kantianism, 1796-1880. Oxford: Oxford University Press, 2014. $610 \mathrm{~s}$.

36. Аскольдов С.А. Теории новейшаго критицизма. (По поводу двух книг) // Вопросы философии и психологии. 1904. Кн. 74. С. 520-549.

37. Яковенко Б.В. Мощь философии. СПб.: Наука, 2000. 976 с.

38. Пустарнаков В.Ф. Университетская философия в России. СПб.: Изд. Русского христианского гуманитарного института, 2003. 916 с.

\section{References}

\section{(Sources)}

Individual Works

1. Chelpanov, G.I. O sovremennykh filosofskikh napravleniyakh [Contemporary Philosophical Directions]. Kiev: Tipografiya Petr Barskiy, 1902. 108 p.

2. Chelpanov, G.I. Problema vospriyatiya prostranstva v svyazi s ucheniem ob apriornosti $i$ vrozhdennosti. Chast' I: Predstavlenie prostranstva s tochki zreniya psikhologii [The Problem of the Perception of Space in Connection with the Doctrine of Its Apriority and Innateness. Part I: The Representation of Space from the Psychological Point of View]. Kiev: Tipografiya Kushnerev, 1896. 387 p.

3. Chelpanov, G.I. Problema vospriyatiya prostranstva v svyazi s ucheniem ob apriornosti $i$ rozhdenii. Ch. II: Predstavlenie prostranstva s tochki zreniya gnoseologii [The Problem of the Perception of Space in Connection with the Doctrine of Apriority and Innateness. Part II: The Representation of Space from the Gnoseological Point of View]. Kiev: Tipografiya Kushnerev, 1904. 429 p.

4. Chelpanov, G.I. Kurs lektsiy po logike [Lecture-Course on Logic]. Kiev: Tipografiya I.I. Chokolova, 1901. 163 p. $785 \mathrm{p}$.

5. Kant, Immanuel. Critique of Pure Reason. Cambridge: Cambridge University Press, 1997.

6. Kant, Immanuel. Theoretical Philosophy after 1781. Cambridge: Cambridge University Press, 2002. $530 \mathrm{p}$.

7. Kant, Immanuel. Theoretical Philosophy, 1755-1770. Cambridge: Cambridge University Press, 1992. 543 p.

8. Askol'dov, S.A. Teorii noveyshago krititsizma. (Po povodu dvukh knig) [Theories of the Latest Criticism. (Concerning Two Books)]. Voprosy filosofii i psikhologii, 1904, book 74, pp. 520-549.

9. Chelpanov, E.I. O prirode vremeni [The Nature of Time]. Voprosy filosofii i psikhologii, 1893, book 19, pp. 36-54.

10. Chelpanov, E.I. Gel'mgol'ts kak filosof i psikholog [Helmholtz as Philosopher and Psychologist]. Voprosy filosofii i psikhologii, 1891, book 10, pp. 41-51. 
11. Chelpanov, G.I. Psikhologiya i teoriya poznaniya [Psychology and the Theory of Cognition]. Voprosy filosofii i psikhologii, 1903, book 66, pp. 97-124; book 67, pp. 167-189.

12. Chelpanov, G.I. K voprosu o vospriyatii prostranstva [On the Problem of the Perception of Space]. Voprosy filosofii i psikhologii, 1897, book 37, pp. 276-287.

13. Chelpanov, G.I. O svobode voli [Freedom of the Will]. Mir Bozhiy, 1897, no. 11, pp. 2-24; no. 12 , pp. $42-65$.

14. Chelpanov, G.I. Filosofiya Kanta. Stat'ya 1-ya (Teoreticheskaya filosofiya) [The Philosophy of Kant. First Article (Theoretical Philosophy)]. Mir Bozhiy, 1901, no. 3, pp. 1-23; no. 4, pp. 165-187; no. 5 , pp. $55-80$.

15. Chelpanov, G.I. Ob apriornykh elementakh poznaniya (Ponyatiya chisla) [The A Priori Elements of Cognition (The Concept of a Number)]. Voprosy filosofii i psikhologii, 1901, book 59, pp. 529-559.

16. Chelpanov, G.I. Ob apriornykh elementakh poznaniya (Ponyatiya vremeni, prichinnosti, prostranstva) [The A Priori Elements of Cognition (The Concept of Time, Causality, Space)]. Voprosy filosofii i psikhologii, 1901, book 60, pp. 699-747.

17. Chelpanov, G.I. Neogeometriya i ee znachenie dlya teorii poznaniya [Neogeometry and Its Significance for the Theory of Cognition]. Voprosy filosofii i psikhologii, 1902, book 65, pp. 13791408 .

18. Chelpanov, G.I. Evolyutsionnyy i kriticheskiy metod v teorii poznaniya [The Evolutionary and the Critical Method in Theory of Cognition]. Mir Bozhiy, 1902, no. 8, pp. 94-117.

19. Grot, N.Ya. [Review of] Chelpanov. Problema vospriyatiya prostranstva v svyazi s ucheniem ob apriornosti i rozhdennosti [The Problem of the Perception of Space in Connection with the Doctrine of Apriority and Innateness]. Voprosy filosofii i psikhologii, 1896, book 35, pp. 651-656.

20. Helmholtz, Hermann. The Origin and Meaning of Geometrical Axioms. Mind, 1876, vol. 1, no. 3 , pp. $301-321$.

21. Chelpanov, G.I. Pamyati prof. N.Ya. Grot [In Memory of Prof. N. Ja. Grot]. Nikolay Yakovlevich Grot v ocherkakh, vospominaniyakh i pis'makh [Nikolaj Jakovlevich Grot in Sketches, Memoirs, and Letters]. Saint-Petersburg: Tipografiya Kushnerev, 1911, pp.185-196.

22. Chelpanov, G.I. Mozg i dusha. Kritika materializma i ocherk sovremennykh ucheniy o dushe [Brain and Soul. Critique of Materialism and an Outline of Modern Doctrines on the Soul]. Kiev: V.A. Prosyanichenko, 1906. 366 p.

23. Chelpanov, G.I. Mozg i dusha. Kritika materializma i ocherk sovremennykh ucheniy o dushe [Brain and Soul. Critique of Materialism and an Outline of Modern Doctrines on the Soul]. Moscow: Kushnerev, 1912. 319 p.

24. Lapshin, Ivan. Filosofskoe znachenie psikhologicheskikh vozzreniy Dzhemsa [Philosophical Significance of James's Psychological Views]. Dzhems, Uill'yam. Psikhologiya [Text Book of Psychology]. Saint-Petersburg: Tipografiya Soykina, 1896, pp. 1-35.

25. Chelpanov, G.I. Vvedenie v filosofiyu [Introduction to Philosophy]. Moscow: Tipografiya V.V. Dumnov, 1916. 568 p.

\section{(Articles from Scientific Journals)}

26. Bocharova, E.B., Vorob'ev, V.S. Maloizvestnye stranitsy zhizni G.I. Chelpanova: k 150-letiyu so dnya rozhdeniya [Little-Known Pages in the Life of Chelpanov: On the $150^{\text {th }}$ Anniversary of his Birth]. Teoreticheskaya i eksperimental'naya psikhologiya, 2012, vol. 5, issue 3, pp. 81-102.

27. Rubtsov, V.V., Serova, O.E., Guseva, E.P. K 150-letiyu so dnya rozhdeniya Georgiya Ivanovicha Chelpanova [On the $150^{\text {th }}$ Anniversary of the Birth of Georgi I. Chelpanov]. Kul'turnoistoricheskaya psikhologiya, 2012, no. 1, pp. 92-109.

\section{(Monographs)}

28. Stumpf, Carl. Über den psychologischen Ursprung der Raumvorstellung. Leipzig: Hirzel, 1873. $324 \mathrm{p}$.

29. Chelpanov, G.I. Kratkiy povtornyy kurs psikhologii [Short Refresher Course in Psychology]. Moscow: «Sotr. shk.» A. Zalesskoy, 1913. 214 p. 
30. Cohen, Hermann. Kants Begründung der Ethik. Berlin: Ferd. Dümmler, 1877. 328 p.

31. Cohen, Hermann. Kants Theorie der Erfahrung. Berlin: Ferd. Dümmler, 1885. 616 p.

32. Cohen, Hermann. Logik der reinen Erkenntniss. Berlin: Bruno Cassirer, 1902. 520 p.

33. Riehl, Alois. Der philosophische Kriticismus und seine Bedeutung für die positive Wisenschaft. Zweiter Band, Erster Theil. Leipzig: Wilhelm Engelmann, 1879. 292 p.

34. Riehl, Alois. Der philosophische Kriticismus und seine Bedeutung für die positive Wisenschaft. Zweiter Band, Zweiter Theil. Leipzig: Wilhelm Engelmann, 1887. 358 p.

35. Riehl, Alois. Introduction to the Theory of Science and Metaphysics. London: Kegan Paul, Trench, Trübner, \& Co., 1894. 346 p.

36. Beiser, Frederick C. The Genesis of Neo-Kantianism, 1796-1880. Oxford: Oxford University Press, 2014. 610 p.

37. Yakovenko, B.V. Moshch' filosofii [The Power of Philosophy]. Saint-Petersburg: Nauka, 2000. 976 p.

38. Pustarnakov, V.F. Universitetskaya filosofiya v Rossii [University Philosophy in Russia]. Saint-Petersburg: Izdanie Russkogo khristianskogo gumanitarnogo instituta, 2003. 916 p.

\section{Реферат}

Можно ли охарактеризовать Георгия Челпанова как неокантианца? Если он был неокантианцем, то каким неокантианцем он был? Более того, как мы можем объяснить его критику в адрес тех, кого в Германии обычно называют неокантианцами? Чтобы ответить на эти вопросы, в данной статье исследуются различные философские и психологические сочинения Г. Челпанова.

Многие из самых ранних публикаций Г. Челпанова посвящены нашему восприятию пространства. Однако он интересовался и нашим субъективным осознанием течения времени. Анализ нашего субъективного ощущения времени и пространства важен для нас. Ученые сегодня часто тесно связывают трансцендентальный идеализм Канта с его защитой априорной природы нашего представления о пространстве и времени. Отстаивал ли Челпанов чисто априорный характер пространства и времени и вместе с ним трансцендентальный идеализм? И возможно ли охарактеризовать его как неокантианца?

В отличие от Канта, Челпанов утверждал, что мы не можем представлять ни время, ни пространство лишенными содержания. По мнению Челпанова, Кант имел в виду не психологическое чувство течения времени, а математическое время. В «Предисловие» к своей магистерской диссертации 1896 г. Челпанов писал, что его основная забота была философской - структура и происхождение нашего представления о пространстве. Он надеялся прояснить проблему с помощью анализа психологических фактов и законов. Обращение к психологии должно было стать лишь предварительным, хотя и необходимым исследованием, чтобы подготовиться к основательному обсуждению философской проблемы.

В начале XX века Челпанов опубликовал несколько философских статей. Цель первого эссе заключалась в том, чтобы определить, существуют ли априорные элементы познания. Обращаясь к понятию числа, он стремился показать, 
что, вопреки эмпиризму, это понятие априорно, а не получено из чувственного опыта. Для Челпанова понятие числа можно проследить до пауз в наших сознательных процессах.

Таким образом, взгляды Челпанова на понятие числа имеют определенные сходства со взглядами Канта. Оба считали это априорным, формальным, основанным на внутреннем сознании времени условием опыта.

Понятие причинности у Челпанова, как и у Канта, априорно. Оно, конечно, не эмпирического происхождения, поскольку в противном случае не было бы необходимым и универсальным. Примечательно, что Челпанов мало что сказал о его генезисе в человеческом сознании. Чего нельзя сказать о концепции пространства. Челпанов, столкнувшись с достижениями математики, стремился отделить наше интуитивное пространство от евклидовой геометрии с ее набором геометрических отношений. Все геометрические формы производятся в сознании и являются идеализациями. На самом деле не существует понастоящему прямых линий, они прямые только в наших мыслях. Тот факт, что геометрия может быть построена с абсолютной последовательностью независимо от опыта, показывает ее приоритетность. Мысленное построение геометрии не зависит от опыта и конкретного пространства с определенными характеристиками. Построение внутренне непротиворечивых геометрий показывает, что понятие пространства эпистемологически априорно, является условием познания и восприятия в целом.

Г. Челпанов утверждал, что для познания необходимы три элемента: 1) многообразие в чувственности; 2) формы пространства и времени; 3) категории, которые являются синтезирующими формами. Он был согласен с большей частью учения Канта в отношении пространства и времени. Но возможно ли принять аргументы Канта и в то же время утверждать, что, хотя наши представления о пространстве и времени обязательно субъективны, все же есть чтото объективное, что-то независимое от нас, что им соответствует?

В 1904 году Челпанов не считал себя кантианским трансцендентальным идеалистом. Однако это не означает, что он должен быть вычеркнут из рядов неокантианства. Он утверждал, что мы должны признать существование трансцендентной реальности, которая обеспечивает материал ощущений. Также должна быть причина, по которой конкретная категория причинности вызывается в некоторых случаях, а не в других. Трансцендентальный реализм, допускающий наличие идеальных элементов в общей реалистической онтологии, был собственной позицией Челпанова. При этом он считал, что это полностью согласуется с текстами Канта и может быть обнаружено в них. Челпанов со своим утверждением о неузнаваемости вещей в себе был даже более кантианцем, чем, например, австро-немец Алоиз Риль, отвергавший их неузнаваемость.

Таким образом, с нашей точки зрения, Челпанов был неокантианцем, хотя и представителем реалистического неокантианского лагеря, в который входили также Риль и Паульсен. 